\title{
THE MODERATING EFFECT OF INTELLECTUAL CAPITAL ON THE RELATIONSHIP BETWEEN CORPORATE GOVERNANCE AND COMPANIES PERFORMANCE IN PAKISTAN
}

\author{
Sajjad Nawaz Khan ${ }^{1, *}$ and Engku Ismail Engku Ali ${ }^{1}$ \\ ${ }^{1}$ School of Accountancy University Utara Malaysia, Malaysia
}

\begin{abstract}
During the global financial crises, the prominence of corporate governance was realized after the major loopholes identified in corporate policies and conspicuous corporate scandals all over the world. Developed countries have passed several laws such as the "Say on Pay" or the "Sarbanes-Oxley Act" to protect the shareholder's wealth. On the contrary, developing countries are still thriving to gain effective corporate governance recognition. This study examined the moderating effect of intellectual capital on the relationship between corporate governance and firm performance. The current study uses four-year panel data from 2012 to 2015. Linear regression, correlated panels corrected standard errors (PCSEs) are used in the analysis. The findings of the study indicate that the intellectual capital has a significant effect on the relationship between board size, board financial expertise, CEO duality, gender diversity and firm performance (ROA). On the other hand, it does not seem to moderate the relationship between board independence and firm performance (ROA). Similarly, the findings indicate that intellectual capital has a significant relationship between board size, board independence, CEO duality, gender diversity and firm performance (ROE) has no moderating effect on the relationship between board financial expertise and firm performance (ROE). Moreover, the empirical results highlight the significance of intellectual capital for regulations and policy making.
\end{abstract}

ARTICLE HISTORY

Received: 05-09-2018

Accepted: $20-11-2018$

\section{KEYWORDS}

Corporate governance,

Performance, Intellectual capital

\section{INTRODUCTION}

Corporate governance is known as a mechanism which plays a very important role in the productivity, profitability, and sustainability of a firm. It also plays a crucial role in encountering the current challenges of the free global environment. These challenges can be handled by the corporate governance through its available intellectual assets. Moreover, the corporate knowledge is one of the essential sources of competitive advantage in business. According to Huang and Liu (2005) intellectual capital is critical to firms' success along with effective corporate governance, and can better explain variances in the companies' financial performance. The global changes in the economy, consisting of complex and competitive situation calls for the contemporary tactics to improve the profitability by managing intellectual capital rather than traditional monitoring of operation by the board (Ting \& Lean, 2009; Ghosh \& Mondal, 2009).

This suggests that firms can attain the balance between effective corporate governance and intellectual capital in multiplicative ways to enhance their performance. Over the years, firm performance has gained considerable attention from many practitioners and academic researchers particularly after the" disaster" of the significant firms in the UK and USA and banking crisis that hit Asia in the late 1990s. In this specific context, the industrial sector of Pakistan is continuously been facing low performance in the shoe, cement, sugar, and textile sector. This leads to a weak economy and affect the foreign investment in Pakistan. Therefore, multinational corporations are unwilling to initiate their business operations in Pakistan and almost 70 percent have already wind-up their operations in Pakistan (Shaikh, 2013). Moreover, the industrial sector in Pakistan is facing huge loses of USD 3.8 billion which is approximately $15 \%$ of government total revenues (ICMAP, 2015). According to CIA (2017), the industrial production growth rate of Pakistan is only 5\%. On the other hand, neighbour competitive countries like Bangladesh, India, and Sri Lanka has growth rate is $8.2 \%, 7.3 \%$ and $5.4 \%$ respectively. This decline in the industrial production indicates poor performance of the sector in Pakistan.

Additionally, Pakistan has also failed to address its business challenges and security risks. Resultantly, country rank decline from 118 in year 2012 to 128 in 2016-2017, among 138 countries, on the Global Competitive Index (WEF, 2016). Strict adherence to corporate policies and regulatory frameworks may help firms improve their performance and contribute positively towards economic growth (Ameer, 2013). Corporate governance plays a significant role in improving firm performance. According to Gregory and Simms (1999), corporate governance effectiveness is related to both external market conditions and the internal organization because strong corporate governance structures could make the firms capable of responding to external conditions effectively. Fatima, Mortimer and Bilal (2018), highlights that firm 
in Pakistan have poor performance due to weak corporate governance. Furthermore, literature provides mixed results on the effect of corporate governance on the firm performance.

According to Aboody and Lev (1998), intellectual capital is the most valuable asset in the presence of a knowledgebased economy that leverage organizations to sustain in the competitive capital market. market. Stabryła (2012), found that the combined effect of corporate governance and intellectual capital could enhance the value of the firm efficiently. This research is specifically aimed at studying the moderating effect of intellectual capital on the relationship between corporate governance and firm performance. The main aim of this research is to report the results of examining the moderating effect of the intellectual capital between corporate governance and companies' performance using a sample of 130 non-financial listed companies operating in Pakistan. Pakistani's non-financial companies need to be address in a better way so as to ensure continued impressive results.

\section{LITERATURE REVIEW}

\section{Board Size}

The advocates of agency and stewardship theory argued that small board size is better than large one because they effectively make decisions and contribute more to the firm performance (Jensen 1993). According to Lipton and Lorsch (1992), large boards may face free riding and social loafing issues and eventually, the effectiveness of board may decrease. There could also be lesser communication issues and greater coordination in the presence of a smaller board size (Jensen 1993). Thus, various supporters of agency theory produced a negative association between board size and firm performance.

Consistent with Che and Langli (2015), considered a sample of Norwegian firms and found that smaller board effectively contributes to firm performance. Kamazima, Mathenge, and Ngui (2017), also explored the negative effect of board size on firm performance. In the reference of Pakistan, Akbar (2014) also provided evidence in favour of agency theory while investigating the relationship between board size and firm performance. Consequently, the following hypothesis is formulated;

$\mathrm{H} 1$ : There is a negative relationship between board size and firm performance.

\section{Board Independence}

Agency theory supports the inclusion of independent or outside directors on the board as they can effectively monitor the activities of agents. Independent directors have no stake in a company, this means that they can take an unbiased decision and align the interests of agents with that of shareholders.

By mitigating agency problems, independent directors contribute significantly towards firm performance (Fama, 1980; Krivogorsky, 2006). Therefore, most of the academic literature found a positive relationship between independent directors and firm performance. Consistent with agency theory, Altuwaijri and Kalyanaraman (2016) found a positive effect of board independence on firm performance in Saudi Arabian non-financial listed companies. Liu et al. (2015) also found similar results in Chinese firms. They also purported that independent directors improve investment efficiency and constraint insider self-dealing. The results of Tavakoli et al. (2016) were also consistent with the agency perspective that a higher percentage of independent directors enhance firm performance in Tunisian firms.

Although there are some studies that investigated either negative or no association between independent directors and firm performance (Cavaco et al. 2016; Johl, Kaur, \& Cooper 2015; Trinh, Duyen, \& Thao, 2015), however, agency theory is more prevalent in the context of Pakistan. There is only one study by Amin, Iftikhar, and Yasir (2013) which is not aligned with agency theory. Nonetheless, the rest of the studies that examined the effect of independent directors on firm performance found a positive outcome (Khan \& Awan, 2012; Zulfiqar \& Shah, 2013; Khan, Ismail, \& Ali, 2018). Therefore, this study also assumes that independent directors could play an effective monitoring role and eventually improve firm performance in reference to Pakistan. Accordingly, by considering this theoretical and empirical evidence, the following hypothesis is formulated:

$\mathrm{H} 2$ : There is a positive relationship between independent directors and firm performance

\section{Board Financial Expertise}

Board financial expertise is the individual knowledge and financial skills of board members that can be developed through experience and education (Yusoff, 2010). In addition to that, the monitoring and oversight role can be effectively instigated by board members if they have adequate financial expertise and qualification (Wang et al., 2015; Khan \& Ali, 2017). The positive effect of board financial expertise on firm performance can be magnificently supported by agency theory.

According to the theory, board members should have sufficient expertise in order to monitor the managerial activities and to collaborate effectively with sub-committees (Moldoveanu \& Martin, 2001). According to Hansell (2003) the knowledge, experience and qualification of board members are strategic resource of firm and their soundness of judgement and higher level of intellectual ability can effectively enhance the firm value. Thus, studies found positive association between board financial expertise and firm performance (Francis, Hasan, \& Wu, 2012; Khan, Ismail, \& Ali, 2018). 
Nonetheless, in the context of Pakistan, there are no prior studies which specifically ensured the effect of board financial expertise on firm performance. Thus, owing to lack of evidence, this study intends to further address the association by taking the proposition of resource dependence theory under investigation. Accordingly, the following hypothesis is generated:

H3: There is a positive relationship between board financial expertise and firm performance

\section{CEO Duality}

According to the advocates of the agency theory, firms could work more productively if the positions of CEO and chairman are held separately (Yermack, 1996). When there is a separation of these positions, firms are more likely to maintain their capital structure effectively (Fosberg, 2004). It also ensured fewer chances of bankruptcy (Ehikioya, 2009). In addition to that, CEO duality is the indicator of weak corporate governance structures (Core, Holthausen, \& Larcker, 1999). The agency theory also asserted that in the presence of CEO duality, excessive power will be possessed by the person who holds the positions and the discretion can be used for rent extraction and private benefits (Finkelstein \& D’Aveni, 1994).

Consistent with the agency perspective, Ujunwa, Salami and Umar (2013) found negative effect of CEO duality on firm performance in Nigerian firms. Similarly, Duru, Iyengar and Zampelli (2016) also found a negative association between CEO duality and firm performance in US listed firms. Similar results were estimated by Shrivastav and Kalsie (2016) in Indian firms. Yang and Zhao (2014) underscores the advantages of CEO duality in making speedy decisions and in saving information costs. Moreover, Tang (2016) investigated US firms and posited that the effect of CEO duality is negative on firm performance as it leads to excessive CEO dominancy. In line with agency theory, (Gull, Saeed, \& Abid, 2013) also found a negative association between CEO duality and firm performance. The current study also assumes that CEO duality exploits shareholder wealth and decrease firm value. Consequently, the following hypothesis is generated with the proposition of agency perspective:

H4: There is a negative relationship between CEO duality and Firm Performance

\section{Gender Diversity}

Generally, researchers have gauged gender diversity as the presence, proportion, and numbers of female representation on the board. Although agency theory does not specifically discuss the role of gender diversity, a diversified board is supported by the theory (Pfeffer \& Salancik, 1978). According to Nekhili and Gatfaoui (2013) women are tough monitors and their inclusion on board can be supported by an agency perspective. Women have better attendance as compared to the male employees (Adams \& Ferreira, 2009), they bring innovative perspective on complicated issues (Francoeur, Labelle, \& Sinclair-Desgagné, 2008). They take more interest in corporate operations by raising several questions (Carter et al., 2003).

According to Green and Homroy (2018), women directors have different cognitive frames (information evaluation processes and information-seeking) as compared to their male colleagues and therefore, they influence firm value. In addition to that, female directors are more likely to have more strength in sales and marketing (Arzubiaga et al., 2017) and better university and advanced degrees (Cumming, Leung, \& Rui, 2015). Therefore, several empirical studies found positive influence of gender diversity on firm performance.

The meta-analysis by (Post and Byron, 2015) revealed that female directors could positively affect firm performance only in the presence of shareholder protection. Christiansen et al. (2016) also found a positive association between gender diversity and firm performance in a large sample of European firms. By utilizing the data of 47 countries (Couto, 2015), purported that there is a significant and positive relationship between women representation and firm performance (both accounting and market-based performance). In the Pakistani perspective, Zahoor (2016) asserted a positive relationship between gender diversity and firm performance. Consistent with agency theory, this study also assumes that women on board effectively monitor the organizational operations which improved operation and market performance. Thus, the following hypothesis is established

H5: There is a positive relationship between gender diversity and firm performance

\section{Moderating Role of Intellectual Capital}

Intellectual capital is basically considered as a knowledge-based asset. This asset comprises the all intangible assets that have economic value but are not physical, e.g. patent, brand, and goodwill (Gerpott, Thomas, \& Hoffmann, 2008). Investments in intellectual capital are very essential in order to enhance firm value. It also helps in creating competitive advantage in the modern and knowledge-based economy (Sardo, Serrasqueiro, \& Alves, 2018). Apposite picture of firm's book and market values can be captured by intellectual capital which cannot be documented in conventional financial ratios. Additionally, Jensen and Meckling (1976) stated that agency conflicts can be mitigated by the collective force of strong corporate governance and intellectual capital efficiency (Khan \& Ali, 2017). According to Organisation for Economic Co-operation and Development (OECD, 2006), reporting, measurement, and management of intellectual assets are also closely linked with corporate governance mechanisms these mechanisms include oversight of risk policy and control, accountability and reporting to shareholders, strategy by the board and monitoring of senior management. High intellectual capital within an organization can protect the rights of minority shareholders and discipline boards and management with positive financial outcomes. 
According to the resource-based view, intellectual capital is very essential to sustain and create the organizational growth opportunities. Strong corporate governance practices and high technical capital both are important to create competitive advantage (Barney, 1991). In the absence of high intellectual capital, corporate governance is less likely to enhance firm growth (Grant, 1996). Therefore, Stabryła (2012) suggested that the integrated effect of corporate governance and intellectual capital could enhance the firm value. In the presence of high intellectual capital, the board of directors and managers are less likely to make detrimental firm decisions (Rajan \& Zingales, 2000). Accordingly, it is expected that intellectual capital can moderate the relationship between corporate governance mechanisms and firm performance. To test this theoretical argument empirically, the following hypothesis and sub-hypotheses are established.

H6: The intellectual capital moderates the relationship between corporate governance and firm performance.

\section{Control Variables}

Control Variable can be defined as the constant variable which clarifies the association between two or more variables. Ignoring control variables from the model could comprise its internal validity (Frankfort-Nachmias, 2007). Majority of the studies who have ensured the effect of corporate governance on firm performance have considered leverage, firm size, and ownership Concentration (Harrison \& Coombs, 2012; Selarka, 2014).

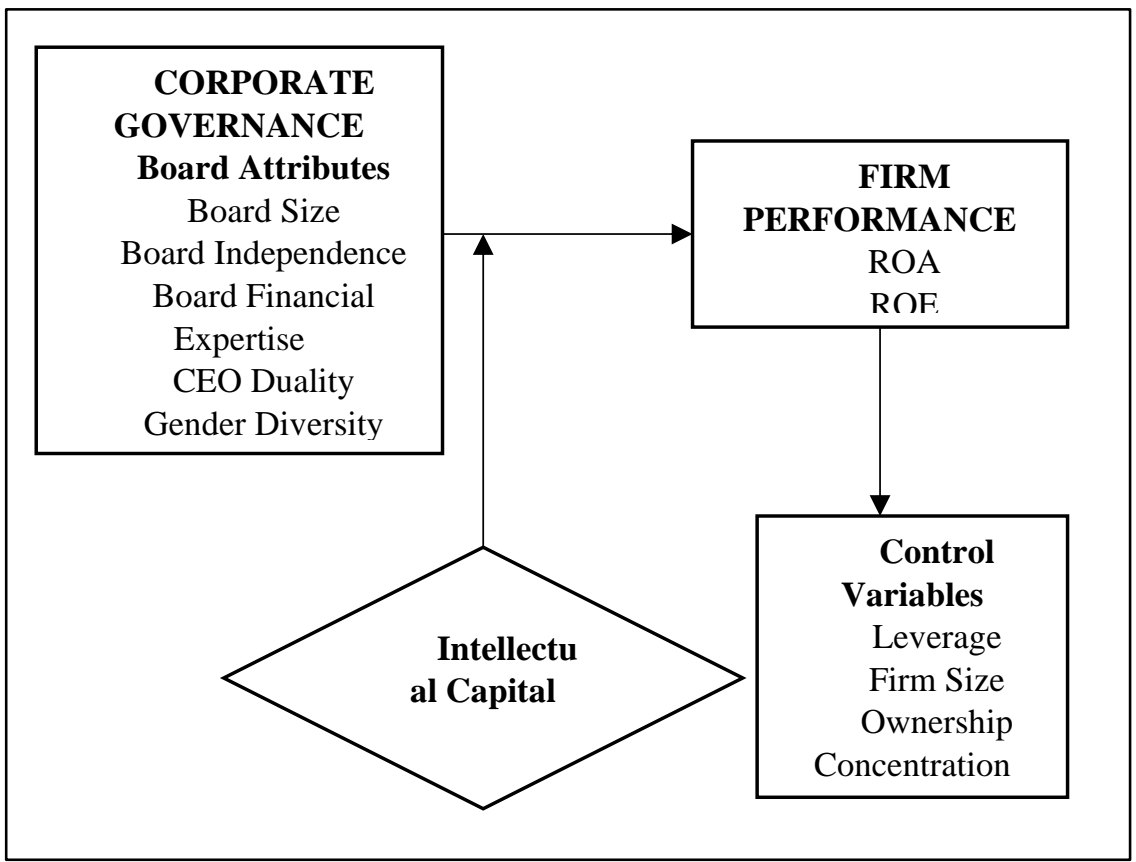

Figure 1: Conceptual framework

\section{METHODOLOGY}

\section{Data}

The aim of this study is to investigate the role of intellectual capital between internal corporate governance and performance of Pakistani firms. Data relevant to intellectual capital, corporate governance attributes, and performance measures were taken from the annual reports of non-financial companies listed on the Pakistan Stock Exchange (PSX) during 2012-2015. Every listed firm is bound to prepare its financial statements in accordance with the approved accounting standards as applicable in Pakistan. The final sample set, after deleting firms with incomplete data, consists of 520 observations for 130 firms over a period of four years. firms included in the sample belong to seven distinct industry groups. These are: cement, chemical, engineering, fuel and energy, paper and board, sugar and allied, textile, and miscellaneous.

\section{Variables}

Based on research objectives, the definitions of the research variables (dependent, explanatory and moderator) were largely taken from the existing literature. Notably, performance measures accounting-based such as Return on Asset and Return on Equity were used as dependent variables. Key explanatory variables include board size, independent directors, board financial expert, CEO duality and gender diversity. Intellectual capital is the moderator. Moreover, few control 
variables such as ownership concentration, leverage, and firm size were included in the estimation model to control the firm-specific characteristics that may affect performance.

In this study, panel data are used because of the sample data contained across the firm and over time. Moreover, the penal data sets are much better to estimate the effects that are not detectable in simple purely time series or cross-sectional data. We employed Panel-Corrected Standard Error (PCSE). Several assumptions of multicollinearity, heteroskedasticity, and autocorrelation are tested on the panel data which determined that the PCSE technique is the best estimator. Prior studies, like Gujarati and Porter (2009) and Pong and Whittington (1994) also suggest that if panel data has heteroskedasticity and autocorrelation issue, then PCSE is the best estimator.

Model

$\mathrm{PER}_{\mathrm{it}}=\alpha+\beta 1\left(\mathrm{BDSZ}_{\mathrm{it}}\right)+\beta 2\left(\mathrm{BDIN}_{\mathrm{it}}\right)+\beta 3\left(\mathrm{BDFX}_{\mathrm{it}}\right)+\beta 4\left(\mathrm{CEODY}_{\mathrm{it}}\right)+\beta 5\left(\mathrm{GEND}_{\mathrm{it}}\right)+\beta 6\left(\mathrm{BDSZ}^{*} \mathrm{IC}_{\mathrm{it}}\right)+\beta 7\left(\mathrm{BDIN}^{*} \mathrm{IC}_{\mathrm{it}}\right)$ $+\beta 8\left(\mathrm{BDFX}^{*} \mathrm{IC}_{\mathrm{it}}\right)+\beta 9\left(\mathrm{CEODY}^{*} \mathrm{IC}_{\mathrm{it}}\right)+\beta 10\left(\mathrm{GEND}^{*} \mathrm{IC}_{\mathrm{it}}\right)+\beta 11\left(\mathrm{SIZE}_{\mathrm{it}}\right)+\beta 23\left(\mathrm{LEV}_{\mathrm{it}}\right)+\beta 24\left(\mathrm{OC}_{\mathrm{it}}\right)+\varepsilon_{\mathrm{it}}$

Table 1: Measurements of variables

\begin{tabular}{|c|c|}
\hline Variables & Measurement \\
\hline Board size & The total number of directors on the board \\
\hline Board independence & $\begin{array}{l}\text { The total number of independent non-executive directors/ total number of } \\
\text { directors }\end{array}$ \\
\hline Board Financial Expert & $\begin{array}{l}\text { The total number of financial and accounting experts on the board/ total number } \\
\text { of directors }\end{array}$ \\
\hline CEO duality & $\begin{array}{l}\text { Dummy variable, i.e. } 1=\text { if the } \mathrm{CEO} \text { also holds the position of chairman, } 0= \\
\text { otherwise }\end{array}$ \\
\hline Gender diversity & The total number of women on the board/ total number of directors \\
\hline Intellectual capital & $\begin{array}{l}\text { VAIC = ICE + CEE (Value added intellectual capital, intellectual capital } \\
\text { efficiency, capital employed efficiently) }\end{array}$ \\
\hline Firm size & Number of years from the time of firm's incorporation \\
\hline Leverage & Total liabilities/ total assets \\
\hline Ownership Concentration & Cumulative percentage of ownership of the five largest owners \\
\hline Return of equity (ROE) & Annual income/ shareholder equity \\
\hline Return on asset (ROA) & Annual income/ total assets \\
\hline
\end{tabular}

\section{RESULTS}

The descriptive statistics of all dependent and independent variable are presented in Table 2:

Table 2: Descriptive statistics

\begin{tabular}{|c|c|c|c|c|c|}
\hline Variable & Observation & Mean & Std. Dev. & Min & Max \\
\hline Board Size (BS) & 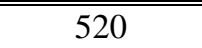 & 8.09 & 1.38 & $\overline{77}$ & 15 \\
\hline Board Independence (BI\%) & 520 & 0.15 & 0.14 & 0 & 0.77 \\
\hline $\begin{array}{l}\text { Board Financial expertise } \\
\text { (BFE\%) }\end{array}$ & 520 & 0.20 & 0.31 & 0 & 5 \\
\hline CEO Duality & 520 & 0.123 & 0.32 & 0 & 1 \\
\hline Gender Diversity (GD) & 520 & 0.129 & 0.26 & 0 & 3.7 \\
\hline $\begin{array}{l}\text { Value added intellectual } \\
\text { capital (VAIC) }\end{array}$ & 520 & 16.49 & 113 & -18.9 & 1915 \\
\hline Leverage (LVG) & 520 & 0.47 & 0.23 & 0.0 & 0.98 \\
\hline Firm size (FS) & 520 & 22.19 & 1.55 & 17.4 & 27.0 \\
\hline $\begin{array}{l}\text { Ownership Constrain } \\
(\mathrm{OWC} \%)\end{array}$ & 520 & 78.77 & 15.6 & 33.38 & 99.88 \\
\hline Return on Asset (ROA) & 520 & 5.93 & 13.1 & -126 & 64.7 \\
\hline Return on Equity (ROE) & 520 & 11.33 & 26.4 & -170.43 & 116.4 \\
\hline
\end{tabular}

\section{Descriptive Statistics}

Table 2 shows that the mean of ROA and ROE is 5.93 and 11.33 respectively. Moreover, the mean of BS is 8.09 and the Board independence mean is $15 \%$. In addition to that, the average representation of the board financial experts is $20 \%$ and CEO duality is 0.12 . Similarly, the average representation on the board is $12 \%$. Furthermore, the mean ownership constrained $78 \%$ and leverage indicates 1.39 . The mean value of intellectual capital is 16.49 . 


\section{Diagnostic Tests}

Regression diagnostic tests must be performed to avoid misleading results and to verify the data's compatibility for the multiple regression analysis before the model is accepted.

Table 3: Breusch-Pagan/Cook-Weisberg Test (Heteroscedasticity test)

\begin{tabular}{ccc}
\hline Chi $^{2}$ (P-value) & ROA & ROE \\
\hline \hline & 0.47 & 0.80 \\
& $(0.49)$ & $(0.37)$ \\
\hline
\end{tabular}

Table 4: Wooldrige Test (Auto Correlation Test)

\begin{tabular}{lcc}
\hline $\mathrm{F}$ & $(1128)$ & $(120.959)$ \\
\hline \hline $\mathrm{P}>\mathrm{F}$ & $\mathrm{P}>\mathrm{f}(0.000)$ & \\
\hline
\end{tabular}

The above Table $3 \&$ Table 4 shows the heteroscedasticity and autocorrelation problem. According to (Gujarati, 2003) the issue of heteroscedasticity and auto correlation can be handled with help of standard error techniques.

Hausman Test (random effect model b/w fixed effect model)

The Hausman specification test is used when running the models to examine whether or not there is a correlation between the explanatory variables and the error term (Baltagi, 2008)

Table 5: Hausman Specification Tests

\begin{tabular}{lll}
\hline Chi2 $\left(\mathrm{P}>\mathrm{Chi}^{2}\right)$ & ROA & ROE \\
\hline \hline & 10.24 & $(7.74)$ \\
& $(0.50)$ & $(0.73)$ \\
\hline
\end{tabular}

The results of Hausman specification indicate the random effect and reject the fixed effect model.

\section{Regression analysis}

This study adopted one model which is showing the direct effect of independent variables on the dependent variables and also showing the moderating effect between independent and dependent variables. The results are presented in the following the Table 6 .

Table 6: Linear regression, correlated panels corrected standard errors (PCSEs)

\begin{tabular}{|c|c|c|c|c|c|c|}
\hline \multirow[b]{2}{*}{ 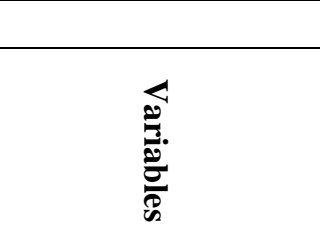 } & \multicolumn{3}{|c|}{ ROA } & \multicolumn{3}{|c|}{ ROE } \\
\hline & 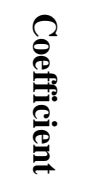 & 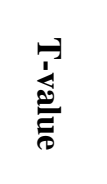 & 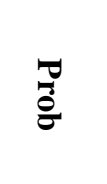 & 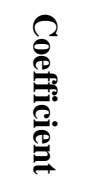 & 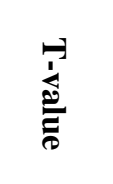 & $\begin{array}{l}\text { Toj } \\
\stackrel{0}{0}\end{array}$ \\
\hline Board size (BS) & 1.29 & 13.4 & 0.000 & 1.33 & 1.83 & 0.067 \\
\hline $\begin{array}{l}\text { Board independence } \\
\text { (BI) }\end{array}$ & 0.76 & 0.24 & 0.808 & 39.1 & 4.61 & 0.000 \\
\hline $\begin{array}{c}\text { Board financial } \\
\text { expert (BFE) }\end{array}$ & 2.49 & 2.87 & 0.004 & 2.64 & 0.72 & 0.47 \\
\hline $\begin{array}{l}\text { CEO duality } \\
\text { (CEOD) }\end{array}$ & -8.72 & -11.09 & 0.000 & -11.1 & -12.08 & 0.000 \\
\hline $\begin{array}{l}\text { Gender Diversity } \\
\text { (GD) }\end{array}$ & -2.90 & -4.34 & 0.000 & -1.34 & -0.55 & 0.586 \\
\hline \multicolumn{7}{|c|}{ Moderator (Intellectual Capital) } \\
\hline ICBS & 0.01 & 1.75 & 0.079 & 0.10 & 2.50 & 0.012 \\
\hline ICBI & -0.47 & -1.19 & 0.236 & -4.51 & -2.64 & 0.008 \\
\hline ICBEF & -0.04 & -1.94 & 0.072 & -0.11 & -0.91 & 0.472 \\
\hline ICCEOD & 0.79 & 4.74 & 0.000 & 1.47 & -21.58 & 0.000 \\
\hline ICGD & -0.22 & -1.97 & 0.049 & -1.25 & -2.54 & 0.011 \\
\hline
\end{tabular}


Table 7: Table 6: Control variables

\begin{tabular}{|c|c|c|c|c|c|c|}
\hline & \multicolumn{3}{|c|}{ ROA } & \multicolumn{3}{|c|}{ ROE } \\
\hline 递. & 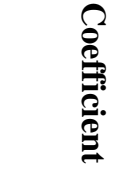 & 承 & $\frac{7}{0}$ & 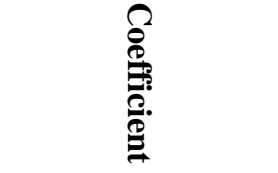 & 是 & $\frac{7}{0}$ \\
\hline \multicolumn{7}{|c|}{ Control Variables } \\
\hline Firm size (FS) & 1.163 & 3.53 & 0.000 & 3.15 & 9.68 & 0.000 \\
\hline Leverage (LVG) & .0803 & 4.92 & 0.000 & 0.16 & 2.54 & 0.011 \\
\hline $\begin{array}{c}\text { Ownership } \\
\text { constrain (OWS) }\end{array}$ & -.0478 & -10.03 & 0.000 & 0.00 & 0.09 & 0.931 \\
\hline Cons & -26.572 & -3.47 & 0.001 & -76.1 & -4.35 & 0.000 \\
\hline $\begin{array}{c}\text { Number of groups } \\
\text { Wald chi }{ }^{2}(4) \\
\mathbf{R}^{2} \\
\text { Prob }>\text { chi }^{2}\end{array}$ & & & $\begin{array}{c}520 \\
130 \\
163.12 \\
0.10 \\
0.0000\end{array}$ & $\begin{array}{l}\text { Number of groups } \\
\text { Wald chi }{ }^{2}(4) \\
\text { R-squared } \\
\text { Prob }>\text { chi }^{2}\end{array}$ & & $\begin{array}{c}520 \\
130 \\
1653.46 \\
0.11 \\
0.000\end{array}$ \\
\hline
\end{tabular}

\section{Summary of Hypotheses}

Table 7 presents the summaries of the findings associated with the hypotheses testing techniques. The analysis displays the moderating role of intellectual capital between corporate governance on firm performance (ROA and ROE). The conflicting result is as follows:

Table 7: Summary of the Hypotheses Testing Results of ROA

\begin{tabular}{clcc}
\hline Ho & \multicolumn{1}{c}{ Hypotheses Statement } & DOA & Decision \\
\hline \hline H1 & $\begin{array}{l}\text { There is a negative relationship between board size and firm } \\
\text { performance. } \\
\text { There is a positive relationship between independent directors and } \\
\text { firm performance } \\
\text { There is a positive relationship between board financial expertise and }\end{array}$ & Not supported & Not supported \\
firm performance & Supported & Supported supported \\
H4 & $\begin{array}{l}\text { There is a negative relationship between CEO duality and Firm } \\
\text { Performance }\end{array}$ & Supported & Supported \\
H5 & $\begin{array}{l}\text { There is a positive relationship between gender diversity and firm } \\
\text { performance } \\
\text { The intellectual capital moderates the relationship between corporate } \\
\text { governance and firm performance }\end{array}$ & Not supported & Not supported \\
\end{tabular}

\section{FINDINGS}

The empirical results show a positive significant relationship between board size and performance. It rejects the predication of agency theory that small board size is better because they take decisions effectively and contribute more to the performance (Jensen, 1993). More importantly, the result may reflect the Pakistan culture and environment where the firms operate. The larger board can bring more resources and reduce the cost in the context of Pakistan. The finding that the board size has a positive relationship with performance is consistent with the findings (Bathula, 2008; Jackling \& Johl, 2009; Khan, Ismail, \& Ali, 2018). Moreover, the board independence shows a positive relationship with the performance, but insignificant with the return of asset and significant with the return on equity. Normally, the larger board independence allows non-executive boards of directors to monitor a firm more closely and take necessary actions. The empirical findings are not giving a clear result with the performance due to the very low (15 percent) representation of independent directors on firms. These results like in the previous studies indicates a positive significant and insignificant with performance of both measures ROA and ROE (Khan \& Awan, 2012; Zulfiqar \& Shah, 2013). Similarly, the board financial expert found the positive insignificant relation between board financial expert with return on asset and positive 
significant with the return on equity. These finding similar previous studies (Wang et al., 2015; Francis, Hasan, \&, Wu, 2012) CEO duality found the negative significant relationship with performance.

So, this finding is similar to the agency theory predictions, suggesting that combining both roles into a single person means to weaken the board control and negatively affect the performance. A negative relationship between CEO duality and performance is consistent with the finding of previous studies (Duru, Iyengar, \& Zampelli, 2016; Shrivastav \& Kalsie, 2016; Ujunwa, Salami, \& Umar, 2013). The gender diversity found the negative relationship with performance. These findings indicate a very low representation (12\%) on the board of Pakistani firms which may the reason of the negative influence on the performance. These findings are in consistent with the previous studies (Naseem et al., 2017; Post \& Byron, 2015).

Moreover, to corporate governance attributes, three control variables were included in the regression equation to control the specific characteristics of a firm that may influence the performance. These control variables include ownership constraints, firm size, and leverage. The empirical results firm size \& leverage find a positive significant relationship with performance are in consistent with the previous studies (Abor, 2007; Gleason, Mathur, \& Mathur, 2000). On the other hand, the ownership constraints in this study found a negative relationship with performance (Chen et al., 2014; Gonzalez et al., 2017).

The empirical results show the intellectual capital moderate significantly with the relationship between board size and performance. On the other hand, the finding indicates the intellectual capital moderating between board independence and performance with measure return on equity but not with the measure with return on asset. In addition to that, the current study shows that the intellectual capital moderates between the relationship of board financial expert and performance measure with the return of asset and not with return on equity. Moreover, the intellectual capital moderates the relationship between the CEO duality and the performance. Similarly, the intellectual capital also shows a moderating effect of gender diversity and performance. This study is in line with the previous studies which were showing the importance of the multiplicative effect of intellectual capital and corporate governance on firm performance (Nkundabanyanga, 2016). So, in the context of Pakistan, the current studies empirical findings indicate that the intellectual capital has an influence on the relationship between corporate governance and performance.

\section{CONCLUSION}

This study examined the moderating effect of intellectual capital between the board governance and performance of non-financial listed firms. The results point out the usefulness of intellectual capital inconsiderable as a sustainable resource for superior wealth creation. The current study offers an important managerial, academic contribution and also contributes to academic research by producing empirical evidence to support theories relevant to the explanation of firms' financial performance. This study has shown that the combination of intellectual capital and corporate governance can be investigated through multi-theoretic approach agency and resource-based theories. In this regard, it is more meaningful to identify the significant positive moderating role of intellectual capital between corporate governance and performance. This current study has shown that ineffective corporate governance and weak intellectual capital are ills vitiating performance improvement in the Pakistan corporate sector. The primary contribution of this study is the moderating effect of intellectual capital on the relationship between corporate governance and firm performance as being overlooked by prior studies. Corporate governance mechanisms in Asian countries are still in the developing stage, therefore, assessing the corporate governance with different components could be more effective as compared to measuring it with BCF or GIM indices. The findings of the study give several practical benefits to the regulatory bodies, policy makers and especially the Securities and Exchange Commission of Pakistan (SECP). Moreover, the result indicates the usefulness and the understanding of intellectual capital which will provide a new innovative way to get the competitive advantage of the companies.

\section{LIMITATIONS AND FUTURE RECOMMENDATIONS}

This study highlighted several contributions regarding the performance of the business in Pakistan, it has some limitations. Firstly, this study covers only the non-financial firms of Pakistan and ignores the financial firms. Therefore, further investigation should cover the overall listed firms of Pakistan.

Secondly, in this study, performance measure only accounting measure return on assets (ROA) and return on equity (ROE) and ignored the market measurement (TQ). Further researches need to consider both performance measurements. It is suggested that panel data technique should be employed rather than general ordinal least square model because it will provide an alternative estimate of the standard errors, identification of the system of equations and consideration of alternative instruments especially robustness checks. This technique may provide consistent results and could enhance the confidence in the findings. The cautious analysis of the model may provide deep insight into the role of effective corporate governance and intellectual in modifying poor firm performance in the capital market of Pakistan. 


\section{REFERENCES}

Amin, Iftikhar-Ul, Nadia Iftikhar, and Muhammad Yasir. 2013. "Board Composition, Ceo Duality and Corporate Financial Performance.” Institute of Management Sciences Peshawar: 1-16. http://www.imsciences.edu.pk/files/journals/Vol. 5 No. 1. April 2013/Paper (2).pdf.

Aboody, David, and Baruch Lev. 1998. "The Value Relevance of Intangibles: The Case of Software Capitalization.” Journal of Accounting Research.

Abor, J. 2007. “Corporate Governance and Financing Decisions of Ghanaian Listed Firms.” Corporate Governance 7(1): 83-92.

Adams, Renée B., and Daniel Ferreira. 2009. “Women in the Boardroom and Their Impact on Governance and Performance.” Journal of Financial Economics.

Akbar, Ahsan. 2014. "Corporate Governance and Firm Performance: Evidence from Textile Sector of Pakistan.” Journal of Asian Business Strategy.

Altuwaijri, Basmah, and Lakshmi Kalyanaraman. 2016. "Is “ Excess ’ Board Independence Good for Firm Performance? An Empirical Investigation of Non-Financial Listed Firms in Saudi Arabia.” International Journal of Financial Research 7(2): 84-92.

Ameer, Beenish. 2013. “Corporate Governance-Issues and Challenges in Pakistan.” International Journal of Academic Research in Business and Social Sciences 3(4): 2222-6990.

Arzubiaga, Unai, Txomin Iturralde, Amaia Maseda, and Josip Kotlar. 2017. "Entrepreneurial Orientation and Firm Performance in Family SMEs : The Moderating Effects of Family, Women, and Strategic Involvement in the Board of Directors." (August).

Baltagi, Badi H. 2008. John Wiley \& Sons, Chichester Econometric Analysis of Panel Data.

Barney, Jay B. 1991. "Firm Resources and Sustained Competitive Advantage." Journal of Management 17(1): 99-120. http://jom.sagepub.com/cgi/doi/10.1177/014920639101700108.

Bathula, H. 2008. "Board Characteristics and Firm Performance: Evidence from New Zealand." Auckland University of Technology 4(1): 1-132. http://aut.researchgateway.ac.nz/handle/10292/376.

Carter, David A. et al. 2003. "Corporate Governance, Board Diversity, and Firm Value." The Financial Review.

Cavaco, S. et al. 2016. "Board Independence and Operating Performance: Analysis on (French) Company and Individual Data." Applied Economics.

Che, L, and J C Langli. 2015. "Governance Structure and Firm Performance in Private Family Firms.” Journal of Business Finance and Accounting.

Chen, V Z, J Li, D M Shapiro, and X X Zhang. 2014. “Ownership Structure and Innovation: An Emerging Market Perspective.” Asia Pacific Journal of Management.

Christiansen, LoneLin, Huidan, Joana Pereira, Petia Topalova, and Rima Turk. 2016. "Gender Diversity in Senior Positions and Firm Performance: Evidence from Europe; by Lone Christiansen, Huidan Lin, Joana Pereira, Petia Topalova, and Rima Turk; IMF Working Paper WP/16/50; March 2016." : 1-29.

CIA World Factbook, (Central Intelligence Agency). 2017. Washington, DC The World Factbook 2017.

Core, J E, R W Holthausen, and D F Larcker. 1999. “Corporate Governance , Chief Executive Officer Compensation , and Firm Performance.” Journal of Financial Economics.

Couto, Eduardo. 2015. "Does the Presence of Independent and Female Directors Impact Firm Performance ? A Multi-Country Study of Board Diversity." (January).

Cumming, Douglas, T. Y. Leung, and Oliver Rui. 2015. “Gender Diversity and Securities Fraud.” Academy of Management Journal 58(5): 1572-93.

Duru, Augustine, Raghavan J. Iyengar, and Ernest M. Zampelli. 2016. "The Dynamic Relationship between CEO Duality and Firm Performance: The Moderating Role of Board Independence.” Journal of Business Research.

Ehikioya, B. I. 2009. "Corporate Governance Structure and Firm Performance in Developing Economies: Evidence from Nigeria.” The international journal of business in society, 9(3): 231-43.

Fama, Eugene F. 1980. "Agency Problems and the Theory of the Firm Agency Problems and the Theory of the Firm." The Journal of Political Economy.

Fatima, S., Mortimer, T., \& Bilal, M. 2018. “Corporate Governance Failures and the Role of Institutional Investors in Pakistan: Lessons to Be Learnt from UK.” International Journal of Law and Management 60(2): 571-85.

Finkelstein, S., And R. A. D’aveni. 1994. "Ceo Duality As A Double-Edged Sword: How Boards Of Directors Balance Entrenchment Avoidance And Unity Of Command.” Academy of Management Journal.

Fosberg, R. H. 2004. “Agency Problems and Debt Financing: Leadership Structure Effects. Corporate Governance.” The international journal of business in society 4(31-38).

Francis, Bill, Iftekhar Hasan, and Qiang Wu. 2012. "Do Corporate Boards Affect Firm Performance? New Evidence from the Financial Crisis.” Bank of Finland Research Discussion Papers.

Francoeur, C, R Labelle, and B Sinclair-Desgagné. 2008. “Gender Diversity in Corporate Governance and Top Management.” Journal of Business Ethics.

Frankfort-Nachmias, C., Nachmias. 2007. Study Guide for Research Methods in the Social Sciences. Macmillan.

Gerpott, Torsten J., Sandra E. Thomas, and Alexander P. Hoffmann. 2008. "Intangible Asset Disclosure in the Telecommunications Industry." Journal of Intellectual Capital. 
Ghosh, Santanu, and Amitava Mondal. 2009. "Indian Software and Pharmaceutical Sector IC and Financial Performance.” Journal of Intellectual Capital.

Gleason, K C, L K Mathur, and I Mathur. 2000. "The Interrelationship between Culture, Capital Structure, and Performance: Evidence from European Retailers.” Journal of Business Research.

Gonzalez, M., C.A. Molina, E. Pablo, and J.W. Rosso. 2017. “The Effect of Ownership Concentration and Composition on Dividends: Evidence from Latin America." Emerging Markets Review.

Grant, Rm. 1996. "Toward a Knoweldge-Based Theory of the Firm.” Strategic Management Journal 17(S2): 109-22.

Green, Colin P., and Swarnodeep Homroy. 2018. "Female Directors, Board Committees and Firm Performance.” European Economic Review 102(January): 19-38.

Gregory, Holly J, and Marsha E Simms. 1999. "Corporate Governance What It Is and Why It Matters." 9th International AntiCorruption Conference (October): 10-15.

Gujarati, D. N. 2003. Basic Econometrics. New York.: McGraw-Hill.

Gull, Ammar Ali, Asif Saeed, and Ammar Abid. 2013. "African Journal of Business Management Corporate Governance and Performance: An Empirical Evidence from Textile Sector of Pakistan.” 7(22): 2112-18. http://www.academicjournals.org/AJBM.

Hansell, C. (2003). 2003. What Directors Need to Know: Corporate Governance. Thomson Carswell.

Harrison, Jeffrey S., and Joseph E. Coombs. 2012. "The Moderating Effects from Corporate Governance Characteristics on the Relationship Between Available Slack and Community-Based Firm Performance.” Journal of Business Ethics 107(4): 40922.

ICMAP. 2015. Proposed Strategy for Economic and Industrial Growth of Pakistan. Karchi.

Jackling, Beverley, and Shireenjit Johl. 2009. "Board Structure and Firm Performance: Evidence from India's Top Companies." Corporate Governance: An International Review 17(4): 492-509.

Jen Huang, Cheng, and Chun Ju Liu. 2005. "Exploration for the Relationship between Innovation, IT and Performance.” Journal of Intellectual Capital.

Jensen, M. C., and W. H. Meckling. 1976. “Theory of the Firm: Managerial Behavior, Agency Costs and Ownership Structure.” Journal of Financial Economics.

Jensen, Michael C. 1993. "The Modern Industrial Revolution, Exit, and the Failure of Internal Control Systems.” Journal of Finance.

Johl, Satirenjit Kaur, Shireenjit Kaur, and Barry J. Cooper. 2015. "Board Characteristics and Firm Performance: Evidence from Malaysian Public Listed Firms." Journal of Economics, Business and Management 3(2): 239-43. http://www.joebm.com/index.php? $m=$ content $\& c=i n d e x \& a=$ show \& catid=40\&id=471.

Kamazima, Benedicta K, Paul Mathenge, and Thomas Ngui. 2017. "Performance : A Case of Listed Commercial Banks in Kenya." 4: $60-82$.

Khan, Aamir, and Sajid Hussain Awan. 2012. "Interdisciplinary Journal of Contemporary Research in Business Effect of Board Composition on Firm's Performance: A Case of Pakistani Listed Companies." Interdisciplinary Journal of Contemporary Research Business 3(10): 853-63. http://journal-archieves15.webs.com/853-863.pdf.

Khan, Sajjad Nawaz, Engku Ismail, and Engku Ali. 2018. "The Influence of Corporate Governance on Firm Performance; Empirical Evidence from Pakistan." 6(5): 58-63.

Krivogorsky, V. 2006. “Ownership, Board Structure, and Performance in Continental Europe.” International Journal of Accounting.

Lecturer, Atiqa Rehman, Syed Zulfiqar, and Ali Shah. 2013. "Board Independence, Ownership Structure and Firm Performance: Evidence from Pakistan.” Interdisciplinary Journal of Contemporary Research in Business.

Lipton, Martin, and Jay W. Lorsch. 1992. “A Modest Proposal for Improved Corporate Governance.” The Business Lawyer.

Liu, Y., M.K. Miletkov, Z. Wei, and T. Yang. 2015. "Board Independence and Firm Performance in China." Journal of Corporate Finance.

Moldoveanu, M, and R Martin. 2001. "Agency Theory and the Design of Efficient Governance Mechanisms.” Rotman School of Management-University of Toronto (May 2014).

Naseem, Muhammad Akram et al. 2017. "Board Attributes and Financial Performance: The Evidence From an Emerging Economy." Journal of Developing $\quad$ Areas $281-97$. http://search.ebscohost.com/login.aspx ?direct=true\&db=bth\&AN=123634173\&site=bsi-live.

Nekhili, Mehdi, and Hayette Gatfaoui. 2013. "Are Demographic Attributes and Firm Characteristics Drivers of Gender Diversity? Investigating Women's Positions on French Boards of Directors." Journal of Business Ethics.

Nkundabanyanga, S. K. 2016. "Board Governance, Intellectual Capital and Firm Performance: Importance of Multiplicative Effects." Journal of Economic and Administrative Sciences 32(1): 20-45.

Organisation for Economic Co-operation and Development (OECD). 2006. "Intellectual Assets and Value Creation: Implications for Corporate Reporting. Corporate Affairs Division, Directorate for Financial and Enterprise Affairs,.” OECD, Paris. (December).

Pfeffer, J, and G R Salancik. 1978. "The External Control of Organizations.” New York.

Post, C., and K. Byron. 2015. "Women on Boards and Firm Financial Performance: A Meta-Analysis.” Academy of Management Journal. 
Rajan, Raghuram G., and Luigi Zingales. 2000. "The Governance of the New Enterprise." Corporate governance, theoretical \& empirical perspectives: 201-32. http://www.nber.org/papers/w7958.

Sajjad Nawaz Khan, Engku Ismail, Engku Ali. 2017. "How Intellectual Capital Moderates the Relationship between Corporate Governance and Firm Performance in the Capital Market of Pakistan: A Conceptual Review and Proposal.” International Journal of Economic Perspectives 11(2): 359-71.

Sardo, Filipe, Zélia Serrasqueiro, and Helena Alves. 2018. "On the Relationship between Intellectual Capital and Financial Performance: A Panel Data Analysis on SME Hotels.” International Journal of Hospitality Management 75(July 2017): 6774. https://doi.org/10.1016/j.ijhm.2018.03.001.

Selarka, E. 2014. “Corporate Governance, Product Market Competition and Firm Performance: Evidence from India.” Springer, Berlin, Heidelberg: $55-77$.

Shaikh. 2013. "Growing Economic Problems of Pakistan,."

Shrivastav, Shikha Mittal, and Anjala Kalsie. 2016. "The Relationship Between CEO Duality and Firm Performance: An Analysis Using Panel Data Approach.” (October).

Stabryła, A. 2012. The Opportunities for and Constraints to Organizational Development in the Information Society. Mfiles pl.

Tavakoli, Sanambar et al. 2016. "Journal of Soft Computing and Decision Support Systems Enterprise Risk Management Adoption and Financial Benefits Creation : Examining the Contributions of COSO ERM Maturity and Board Of." 3(3): 13-19.

Ting, Irene Wei Kiong, and Hooi Hooi Lean. 2009. "Intellectual Capital Performance of Financial Institutions in Malaysia." Journal of Intellectual Capital.

Trinh, T. H., T. T. Duyen, and Thao N. T. 2015. “The Impact of Corporate Governance on Financial Risk in Vietnamese Commercial Banks." International Journal of Economics and Finance.

Ujunwa, A, P O Salami, and A H Umar. 2013. "CEO Duality and Firm Performance: An Integration of Institutional Perceptive with Agency Theory.” International Journal of Social, Behavioral, Educational, Economic, Business and Industrial Engineering 7(1): 180-86.

Wang, Cong et al. 2015. "Industry Expertise of Independent Directors and Board Monitoring.” Journal of Financial and Quantitative Analysis.

WEF. 2016. World Economic Forum Reports 2016 The Global Competitiveness Report 2016-2017.

Yermack, David. 1996. "Higher Market Valuation of Companies with a Small Board of Directors.” Journal of Financial Economics.

Yusoff, WFW. 2010. "Characteristics of Boards of Directors and Board Effectiveness: A Study of Malaysian Public Listed Companies." Victoria University-PHD.

Zahoor, Nida. 2016. "Relationship between Gender Diversity in Top Management Teams and Profitability of Pakistani Firms." 16(1997): 89-93. 